Crime, Histoire \& Sociétés / Crime, History \& Societies

Vol. 5, n`2 | 2001

Varia

\title{
Violence and the civilizing process : does it work?
}

\section{Pieter Spierenburg}

\section{OpenEdition}

\section{Journals}

Electronic version

URL: https://journals.openedition.org/chs/740

DOI: $10.4000 /$ chs. 740

ISSN: 1663-4837

\section{Publisher}

Librairie Droz

\section{Printed version}

Date of publication: 1 January 2001

Number of pages: $87-105$

ISBN: 2-600-00664-8

ISSN: $1422-0857$

\section{Electronic reference}

Pieter Spierenburg, "Violence and the civilizing process : does it work ?", Crime, Histoire \& Sociétés / Crime, History \& Societies [Online], Vol. 5, n² | 2001, Online since 02 April 2009, connection on 23 March 2022. URL: http://journals.openedition.org/chs/740 ; DOI: https://doi.org/10.4000/chs.740 


\title{
Violence and the civilizing process: does it work?
}

\author{
Pieter Spierenburg
}

\begin{abstract}
Among historians, especially those investigating violence, Norbert Elias' theory of civilization has received divergent appreciations recently. In the Anglo-Saxon world, notably in North America, it has obtained increasing recognition over the last ten years or so. In particular, many authors agree that he offers the only theoretical framework which easily accomodates the empirical evidence on the long-term decline of homicide. Conversely, in Continental Europe during the 1990s, a number of historians, notably German historians of crime, have criticized Elias' work. In this discussion, too, the subject of violence looms large.

This discussion article confronts the criticism levelled at the theory of civilization, in so far as it pertains to violence. It deals with four broad clusters of problems: (1) the reliability and validity of the evidence for the longterm trend of declining violence; (2) the character of violence, in particular its function as an indicator for the level of behavioral control; (3) the interdependence of long-term change in the field of aggression and human emotions on the one hand and the overall development of society on the other; (4) the new wave of interpersonal violence in the Western world in the late twentieth century.

It will be concluded that research on the long-term development of homicide over the last twenty years has yielded impressive new evidence for the theory of civilization, which some historians nevertheless tend to ignore or attempt to explain away. The only objection to the theory not based on a misinterpretation refers to the historical study of honor and ritual. None of the data generated by this research, however, are incompatible with the processes first observed by Elias. Contrary to what his critics assume, the theory of civilization invites creative elaboration, which should be the aim of future research.
\end{abstract}

Parmi les historiens, en particulier ceux qui s'intéressent à la violence, la théorie de la civilisation des mours de Norbert Elias a récemment fait l'objet d'appréciations divergentes. Dans le monde anglo-saxon, et en particulier en

1 Pieter Spierenburg is affiliated with the history department of Erasmus University, Rotterdam and the Posthumus Institute (a Dutch research school). In 2001 he was a visiting professor at Carnegie Mellon University, Pittsburgh. His main interests are the history of violence from a comparative and theoretical perspective and European socio-cultural history. His publications include: The Spectacle of Suffering. Executions and the Evolution of Repression: from a Preindustrial Metropolis to the European Experience, Cambridge (Cambridge UP), 1984; The Prison Experience. Disciplinary Institutions and their Inmates in Early Modern Europe, New Brunswick, NJ (Rutgers UP), 1991; (editor) Men and Violence. Gender, Honor and Rituals in Modern Europe and America, Columbus OH (Ohio State UP), 1998. 
Amérique du Nord, elle a connu une faveur croissante depuis une dizaine d'années. De nombreux auteurs admettent, en particulier, qu'elle constitue le seul cadre théorique qui soit compatible avec les preuves empiriques d'un déclin de l'homicide sur le long terme. Inversement, en Europe, plusieurs auteurs, notamment des historiens allemands de la criminalité, ont critiqué le travail d'Elias au cours des années 1990. Dans cette discussion également, la question de la violence occupe une part importante.

Cet article discute les critiques adressées à la théorie de la civilisation des maurs qui ont trait à la question de la violence. Il traite de quatre groupes de problèmes. (1) la fiabilité et la validité des données relatives à la tendance au déclin de la violence dans la longue durée; (2) le caractère de la violence et en particulier sa fonction d'indicateur du niveau de contrôle du comportement; (3) l'interdépendance entre, d'une part, le développement global de la société et, d'autre part, les changements dans le long terme dans le domaine de l'agressivité et des émotions; (4) la nouvelle vague de violence interpersonnelle dans le monde occidental de la fin du XX siècle.

On concluera que les recherches de ces vingt dernières années sur l'évolution pluriséculaire de l'homicide ont apporté d'impressionnantes confirmations de la théorie de la civilisation des mours, que certains historiens tendent néanmoins à ignorer ou à contester. La seule objection qui ne soit pas basée sur une mésinterprétation de cette théorie réfère à l'approche historique de l'honneur et des rites. Toutefois, aucune donnée produite par ces recherches n'est incompatible avec le processus observé pour la première fois par Elias. Contrairement à la position de ses critiques, la théorie de la civilisation des mours invite à la créativité scientifique, objectif qui devrait guider les recherches futures.

cholars who get excited by record-breaking figures must love the abbot Don $D$ Gregorio Salvini. In a book published in 1758 he refers to a survey, ostensibly conducted by Corsica's Genoan overlords in 1715 : during the preceding thirtytwo years no less than 28715 homicides had been committed on the island ${ }^{2}$. If true, this would yield a murder rate making the top figures cited most often in historical works - for fourteenth-century Florence and Oxford and a few mining towns on the American frontier - appear insignificant ${ }^{3}$. Moreover, the Corsican case definitely meets the methodological requirement of sufficient size ( 8722 square km.) and evidence over a sufficiently long time span. The island's population in the seventeenth and eighteenth centuries has traditionally been estimated at 120000 , but in the most recent synthesis of its early modern history a figure of around 150000 is assumed to be more realistic ${ }^{4}$. In the latter case, the homicide rate for the period 1683-1714 comes at 598 per 100000 inhabitants per year; if we cling to the older population estimate, it would rise to 747, which, if anything else, is an appropriate number for a skyrocketing figure.

Does the question, 747 or 598 , really matter? Of course it would be unwise to take the surprisingly precise number of homicides reported by Salvini for granted,

2 Salvini (1758, p. 80). I am indebted to prof. Antoine-Marie Graziani for directing me to this work, which is the (only) original source for all discussions of the figure in question in historical literature.

3 Becker (1976, p. 287); the figures of pp. 152 and 68 for Florence both refer to a period of only 4 years, so they should be averaged to 110 ; Hammer (1978, p. 11); Courtwright (1996, p. 82).

4 Arrighi ed. (1971, p. 276); Graziani (1997, p. 89). 
even though the abbot claimed he had it from a governmental document. The avowed purpose of his book was to expose the failures of the Genoese administration in Corsica, in this case the regime's fomentation of «civil discord». We can discard his revolutionary bias, of course, if he had correctly taken the number in question from an administrative document (which we do not know) 5 . Even then, it is unlikely that the reported figure of 28715 homicides was based on a thorough and reliable investigation. In 1715 , the Genoese administration itself had every reason to exaggerate. It had just instituted a tax on the possession of firearms in Corsica, in an attempt to pacify the island. For this reason, the leading historian of early modern Corsica, Antoine-Marie Graziani, considers the figure in question completely meaningless ${ }^{6}$.

Nonetheless, whatever the degree of exaggeration, Corsica around 1700 was by no means a peaceful place. Salvini's claim that it was all Genoa's fault, does not diminish the reality of social conflict. Graziani himself speaks of an «extreme degree of violence» pervading early modern Corsican society. Priests, too, walked around armed, even in church, and they avenged their family honor by killing members of enemy factions. The number of bandits was kept in check only because many of them decided to try their luck in Sardinia or the mainland ${ }^{7}$. Moreover, blood feuds and banditry still were endemic in Corsica during most of the nineteenth century, as evidenced by Stephen Wilson's well-known study. Wilson has calculated homicide rates ranging between 26 and 64 per 100,000 inhabitants (annual averages in five-year periods) during the years $1816-1850^{8}$. There is no reason to assume a priori that they were lower in the early modern period. Indeed, another contemporary; Ajaccio's bishop Giustiniani, wrote in 1604 that, during his seventeen years of office, he had personally witnessed the killing of at least a hundred men. This would imply an annual homicide rate for the town of Ajaccio - one more exaggeration, no doubt - of over 294 per $100000^{9}$. During a large part of its history, then, the inhabitants of Corsica were decidedly more violent, on average, than their contemporaries in mainstream Europe.

The case of Corsica highlights the exceptions and discontinuities which marked the development of interpersonal violence in Europe. There was no unilinear and universal evolution from a violent to a less violent society. Norbert Elias' theory of civilization, some scholars believe, implies just such an evolution. That sort of simplistic interpretation of his theory can easily be corrected ${ }^{10}$. Other criticisms, however, may prove a little harder to handle. The purpose of this essay is to re-assess

5 I was unable to trace such a document during a brief visit to the Archivio di Stato in Genoa. I am grateful to its director, dr. Carlo Bitossi, for his help.

6 E-mail correspondence between myself and prof. Graziani, July-November 2000.

7 Graziani (1993 \& 1997, pp. 146-174) (quote on p. 166). The involvement of priests casts doubt on Wilson's thesis that feuds increased in severity in the 19th century, because of a growing disrespect for mitigating rules such as the immunity of certain categories of persons, among whom priests (Wilson, 1988, pp. 53-54, 207).

8 Wilson (1988, p. 16).

9 Giustiniani cited in Graziani (1997,pp. 166-167). Ajaccio had about 2000 inhabitants at the beginning of the 17th century (p. 105).

10 This theory was first outlined in (Elias, 1939), but I will emphasize the unity of his entire work and the contribution to his theory by other scholars. 
the explanatory value of the theory of civilization in the light of historical data on interpersonal violence. That effort includes a response to some of Elias' critics.

Among historians, especially those investigating violence, the theory of civilization has received divergent appreciations recently. In the Anglo-Saxon world, notably in North America, it has obtained increasing recognition over the last ten years or so. In particular, the growing interest in the subject of the long-term development of homicide has put Elias' work on the scholarly agenda. Most authors agree that he offers the only theoretical framework which easily accomodates the empirical evidence on the long-term decline of homicide ${ }^{11}$. It must be added that the authors in question are mostly content with making this observation and undertake little effort to elaborate on Elias' analysis. Conversely, in Continental Europe during the 1990s, a number of historians have criticized Elias' work. Some medievalists, for example, argue that he presents a distorted picture of life in the middle ages. In this discussion, too, the subject of violence looms large. Among German crime historians it now has become almost commonplace to reject the theory of civilization. It is less clear, though, what they propose in its place.

The criticism from Continental scholars varies in its degree of sophistication. Some of it is rather superficial. In a collective volume entitled Kulturen der Gewalt, for example, several contributors, though not all, implicitly or explicitly argue against Elias. In the introduction, Rolf Peter Sieferle plays the trick of associating Elias with Hobbes and calls the former's theory a simple, linear narrative, which it indeed is in Sieferle's «summary ${ }^{12}$. Martin Dinges attempts to confront the theory of civilization head-on, an effort which utterly fails because he is only fighting the windmills of his own bizarre caricature. For example, Dinges claims that Elias stresses the «otherness » and strangeness of violence, relegating it to the realm of «cultural deserts» ${ }^{13}$. Although totally unfounded, this objection is intriguing because it forms the exact opposite of the reproach made by some medievalists: that Elias considers violence as a normal and omnipresent feature of medieval life. By contrast, a recent article by Gerd Schwerhoff offers a more sophisticated critique of the theory of civilization. Schwerhoff is aware that this theory concerns more than just violence and provides an almost impeccable summary. In the end, however, his essay betrays a structural bias: he cites a number of - mostly historical - studies published since 1939 which (appear to) contradict what Elias wrote, but he omits the numerous studies published since then which confirm his theory ${ }^{14}$. Most of the objections raised by Dinges and Schwerhoff will be dealt with below.

An author is always well-advised if he controls his own passions, so I must refrain from a too-detailed refutation of the arguments of every scholar I disagree with. For the sake of systematization, let me group the objections levelled against the theory of civilization, in so far as they pertain to violence, into four broad clusters: (1) the reliability and validity of the evidence for the long-term trend of declin-

11 Gurr (1981, pp. 341-342) was probably the first. More recently in the editors' introduction to Johnson, Monkkonen (1996).

12 Sieferle in Sieferle, Breuninger (1998, pp. 9-29; here pp. 14-15). The counter-example in this volume is Cristoph Marx's article on South-Africa (pp. 215-240) which makes creative use of Elias' theory.

13 Dinges in Sieferle, Breuninger (1998, pp. 171-194; esp. pp. 176-178). In a similar vein, Arlette Farge claims that Elias is silent about «l'intérieur de la violence, les formes de ce phénomène qui relèvent de la rationalité» (Burguière et al., 1995, p. 224).

i4 Schwerhoff (1998). Summary of Elias on pp. 568-573. 
ing violence; (2) the character of violence, in particular its function as an indicator for the level of behavioral control; (3) the interdependence of long-term change in the field of aggression and human emotions on the one hand and the overall development of society on the other; (4) the new wave of interpersonal violence in the Western world in the late twentieth century. At several points in my discussion it will be necessary to clear up misunderstandings, for which I apologize in advance. It actually testifies to the strength of the theory of civilization that its persistent critics have only been able to present a seemingly plausible argument by misrepresenting it.

Was the long-term decline of violence, from the fourteenth century to the middle of the twentieth, real? Obviously, this is a methodological problem of concern to all researchers in the field, whether or not they accept the theory of civilization. Most of them do agree that the quantitative evidence on homicide points at a real decrease in the amount of killing. By contrast, in their enthusiasm for piling up one criticism of Elias on the other, both Schwerhoff and Dinges question this widely shared view. The first even proposes to reconsider the common habit of treating homicide figures based on prosecuted cases alone as suspect. «The widespread practice of considering the highest available rates as those nearest to reality $»$ he says, «has a certain arbitrariness to it ${ }^{15}$.

Why not take low rates for real for a change, this statement implies. In fact, no researcher, whether following Elias or not, advocates a method of always accepting the highest figures reported. For example, if a ninth-century chronicler writes that a thousand Vikings attacked his town, the historian takes this number cum grano salis. I just did the same with the amount of murders claimed by Salvini and we should do this in all similar cases. The real criterion is not the highest but the best estimate. For that reason, demographic historians regularly reject reported population figures as either too high or too low. It just happens that, for homicide, body inspections are our best measure, especially before the age of statistics and journalism. Conversely, figures for prosecuted homicide do not always yield the lowest rates. In modern times they often include attempts, yielding figures much above those derived from contemporary medical statistics.

Ongoing work by Manuel Eisner represents the most exhaustive effort of collecting data, from a host of scattered publications, on homicide figures from the European past ${ }^{16}$. Even his data base, I think, occasionally underestimates the number of murders. Notably, Eisner has included a few older studies of places in late medieval and early modern England which are based on indictments alone. As I have argued earlier, Gurr's original graph for England starts off at a too modest level ${ }^{17}$. Moreover, the incredibly low homicide rates (around 0.7 ) in Swedish national statistics beginning in the mid-eighteenth century are doubly inflated: not only are they probably based on court cases (Österberg does not specify this), they are relative to the number of inhabitants aged $15-69^{18}$. Correction for the latter factor

15 Schwerhoff (1999, p. 119).

16 Reported in Eisner (2000, conference paper). To appear in British Journal of Criminology, 2001/4.

17 Spierenburg in Johnson, Monkkonen (1996, pp. 65, 95). This argument gets support from Roth's analysis (this issue).

18 Österberg in Johnson, Monkkonen (1996, pp. 43-44). Neither does she discuss the source for the national statistics in earlier publications where she uses them. 
would at least bring them near to one. Despite these considerations, Eisner's conclusion on the long-term trend in Europe is inescapable: «the evidence is so consistent, the secular decline so regular and the differences in levels so large, that it seems difficult to refute the conclusion of a real and notable decline ${ }^{19}$.

It is one thing to observe a decreasing trend in homicide, it is another to conclude that violence in general has declined. Although several scholars feel unhappy with this extrapolation, only Dinges, to my knowledge, has maintained that the level of nonlethal violence actually has increased. The basis for this is very meager: a few French studies show a rise in prosecutions for violent offenses toward the end of the eighteenth century and studies of marital conflict reveal a lot of battering and assault within families in the eighteenth century and the first half of the nineteenth ${ }^{20}$. The latter observation says nothing about the prevalence of domestic fights in an earlier or later period. Moreover, one of Dinges' sources, David Sabean, actually observes a shift from «systematic» to «reactive» violence by husbands around 1800 , which rather suggests a decline in overall marital violence ${ }^{21}$. The question of husbands beating their wives has been heavily debated among family historians. Although they disagree over the timing of change, most agree on a declining trend somewhere between the sixteenth and twentieth centuries. The trajectories of this trend in various countries should of course be established with greater precision, but for the moment we observe that its direction is congruent with the overall development regarding interpersonal violence.

To be sure, high levels of homicide are usually due to a prevalence of male-onmale fighting. We are justified in taking these homicides as indicators for a broader reservoir of violence, because they commonly are "accidents», cases in which a fight got out of hand ${ }^{22}$. Accepting this, one might still argue that, if men's aggressive impulses become stronger, both their willingness to attack others increases and the proportion of fights with an «accidental», lethal outcome. The consequence, for the sake of argument, can be stated in quantitative terms: in order to prove a doubling of men's aggressive impulses over a certain period, we need a quadrupling of homicides and to substantiate a $50 \%$ decline, a division by a factor of four is needed. Obviously, with a long-term trend of several dozens to under one, this is no problem.

Quantification alone never tells the whole story. No one would argue that nonlethal violence, including mere threatening, should be left from consideration by historians, or that the study of assault and fighting produces only trivial knowledge. It just happens to be the case that, to establish the sheer amount of violence in a society, homicide rates are our only reliable indicator ${ }^{23}$. With just the rates of prosecution available, increases or decreases in nonlethal violence may reflect anything. In other words, although fights, assaults and threats constitute a subject highly worth

19 Eisner (2000, p. 11).

20 Dinges in Sieferle, Breuninger (1998, pp. 175, 186).

21 Sabean (1990, pp. 133-134).

22 I discussed this more elaborately in my contribution to Johnson, Monkkonen (1996, p. 74). I found no counter-argument in more recent literature.

23 The only other possibility is when some town or region obliged its surgeons to report the violently inflicted wounds they treated and a complete series of reports has survived. I have found no study in which these two requirements were met, but the preliminary one by Bartolini (1999) points in that direction. 
studying, any count of them is unable to prove or disprove the long-term decline in violence. Informed estimates based on prosecuted rates are of course possible. Two English studies, by Beattie for the eighteenth century and Gatrell for the second half of the nineteenth, are generally acclaimed for the sophistication of their quantitative analysis. The authors carefully weighed all possible factors influencing their figures, which enabled them to extrapolate convincingly from prosecuted rates of nonlethal assault to real rates. Both authors conclude toward a decline of violence ${ }^{24}$.

A final point in this cluster of problems concerns the population side of calculating homicide rates. In his dissertation, not that critical of the dominant method yet, Schwerhoff already expressed some doubt: in modern times, even a «sleepy provincial town $»$ easily assembles 50000 people within its confines ${ }^{25}$. The implication is that the twentieth century's low homicide rates are biased because of the «unfairly high numbers» of inhabitants. One could easily turn this argument around: people living in $\mathbf{1 5 0 0}$ would find it amazing that a town of that size can be sleepy. The question is what do you want your homicide rates to speak for. One important thing they testify to, I argue, is contemporaries' direct experience with violence. If a town of 5000 inhabitants witnesses three murders per year, it means that every neighborhood community has first-hand experience with killing. Today, not to mention in the 1950s, many neighborhood communities have no direct experience with killing at all. Their members live in a world in which aggressive emotions are kept in check to a large extent. Viewed from that angle, it is equally unnecessary to control homicide rates for such factors as the proportion of young men in the population. This factor can simply figure among the explanations for regional and short-term variations in the rates. Whatever the age structure, it leaves the bare fact of the total population's experience with violence unaltered. Whereas it is true that in every society we know of violence is practiced disproportionately by young males, practice alone does not tell us much about an entire community's attitude. During a feud, for example, older men, or women for that matter, may encourage youths to avenge the family honor ${ }^{26}$.

The subject of honor smoothly leads to my second theme, that of the character and context of violence. This is a contested area, in particular for the period when homicide rates were high: the middle ages. Incidentally, in my opinion «middle ages $\gg$ is a misleading and useless term, which should be banned from historical writing. In our discussion, the term essentially refers to (the urban world of) the late thirteenth through early sixteenth centuries. For brevity's sake, despite my reservations, I will refer to this period as «the middle ages».

Apart from indulging in fights, this was also a time in which people ate with their hands, urinated in public, bathed naked and shared beds with complete strangers. According to the theory of civilization, the degree of control over affects and impulses was lower and sudden shifts from one mood to another occurred more frequently than in later periods. Note the comparative wording here. Lesser control is not the same as no control. Elias always emphasized that processes of civilization

\footnotetext{
24 Gatrell (1980); Beattie (1986).

25 Schwerhoff $(1991$, p. 286).

26 Among Turks in the Netherlands today, families often require adolescents, who cannot be tried as adults, to kill for honor. See van Eck (2001).
} 
have no beginning: in any society people control their emotions to some degree. Moreover, the relatively low level of emotional control prevailing in the middle ages was just as much a habitus which had to be learned, into which the young had to be socialized, as the court etiquette of Versailles. Given this, it is certainly unjustified that some historians continue to write as if Elias viewed medieval life in terms of a static «we-they» contrast. Any criticism based on the mistaken notion that Elias postulated a zero point of civilization can simply be dismissed.

Passages coming near to this view can nevertheless be found in the historical literature on violence. Thus, the French medievalist Claude Gauvard chides Elias for having observed in the middle ages nothing but an «instinctive and brutal barbarity ${ }^{27}$. German historians followed suit: in line with Huizinga, he has painted a naîve picture of quickly changing moods ${ }^{28}$; he succumbed to « the myth of the wild and dark middle ages ${ }^{29}$. Taking issue with his use of the famous Hausbuch as a source of information about knightly life, Schwerhoff once more overstates his point. Modern investigators have shown that various artists worked on the Hausbuch and that several patrons fostered it, Schwerhoff triumphantly remarks, as if this would not rather raise its value as an illustration of contemporary customs ${ }^{30}$. Finally, in an amusing note, Valentin Groebner gave the reproach of a naïve view of the middle ages a new twist: Elias actually loved the middle ages. It is no coincidence, Groebner says, that he described the untamed lust for violence in what this historian considers «sexually loaded terms . Whether Elias wrote about fighting or love-making, it all sprang from «a nostalgia for a lost intensity and authenticity of feelings $»^{31}$.

Groebner's statement is amusing, because he apparently thinks he has made a «discovery». It is irrelevant to the theory of civilization, however, whether someone thinks its author was seized by a nostalgic longing or a stomach ache when contemplating medieval life. Such comments tell us more about the personality of the scholars who make them than about the theory they ostensibly criticize. Historians like Groebner suppose there simply must be a personal value judgment in Elias' work; they are unable to accept his main motive was to interpret the sources. By contrast, in a more realistic approach, the observer may acknowledge that one and the same historical process can involve elements which an individual possibly likes as well as those he possibly dislikes: gains and losses, if you wish. Thus, we might say that civilizing processes imply both an increase in politeness and a decrease in spontaneity.

The criticism discussed so far is largely devoid of content. The only serious objection which does refer to a matter of content, concerns the twin themes of ritual and honor. The ritualization of violence and its embeddedness in an honor code, a number of scholars claim, belie Elias' picture of medieval life as relatively free from emotional controls. Again, Gauvard was one of the first to present this argument, but she merely posits it in the introduction and conclusion of her voluminous study. Honor, she explains, was a value shared by all social classes. The fact that violent

\footnotetext{
27 Gauvard (1991, p. 944).

28 Schuster (1995, pp. 96-98).

29 Schwerhoff $(1998,601)$. Similar in Schwerhoff $(1999$, p. 121).

30 Schwerhoff $(1998$, p. 579).

31 Groebner (1995, p. 165).
} 
behavior was usually bound to the rules of the honor code means that affects were constrained after all, hence a considerable blow to the theory of civilization. Gauvard does not illustrate this with concrete examples though. Another weak point concerns her continuous confusion between violence and criminality in general: low crime rates automatically translate into a low level of violence. Finally, she writes as if society is a person who acts, even producing the curious sentence «society has made rules to protect itself against itself ${ }^{32}$.

Arguing in a similar vein, Schuster introduces a concrete example, an incident in fifteenth-century Basel: everything is peaceful on the fish market in the early evening; a few words from a passer-by alter the situation; suddenly two people are fighting with knives. Then Schuster reveals that the incident had a previous history: the two fighters had quarrelled the other day and the passer-by knew he was likely to encounter his opponent again on the fish market. This kind of purposeful action, Schuster continues, was typical of medieval conflicts. He considers the fact that third parties often tried to stop a fight as another argument against Elias' theory ${ }^{33}$. One wonders why Schuster did not begin his story with the incident of the other day and whether the angry man perhaps had decided in an impulse to walk to the fish market. This example merely illustrates that some conflicts lasted for a longer time, a fact which Elias knew all too well of course. We have no proof yet that honor and ritual were incompatible with free-floating emotions.

In this matter, Dinges presents the most ingenious argument. According to him, honor and ritual functioned as pacifying factors: «The most important consequence of the ritualization of violence is the opportunity [it offers] to get out of a violent confrontation and peacefully concede to the demands of the other party". Consequently, ritual is a zweckrational phenomenon ${ }^{34}$. Dinges bases this explicit conclusion on the more implicit ones in his book on conflict in eighteenth-century Paris. In that perceptive study he shows that even the seemingly most trivial behavior of common people acquires meaning within the context of honor games. Every action has its symbolic significance; nothing is just random. A confrontation may end in bloodshed or go no further than verbal threats, but rituals accompany it at every stage. Based on the evidence, Dinges constructs an ideal-type scenario of a slowly escalating quarrel. Verbal threats are followed by gestures: «In these carefully ordered gestures, we note again their precisely calculated, ritualized character of threatening $»^{35}$.

His choice of words is revealing. Ritual involves calculation, Dinges implies, and therefore affect control. If one of his Parisians struck another with his fist, this was part of a scenario which the attacker had planned, as it were, five days earlier and had tested and refined in his thoughts. Here we have Dinges' fundamental mistake. The repetitive nature of his scenario does not point at planning or calculation. Ritual implies a fixed pattern! That pattern is already in people's heads; it does not have to be invented. Consequently, the ritual character of many violent confrontations does not preclude that they arose out of impulse. This applies with equal

32 Gauvard (1991; paraphrased quote on p. 700). See also Gauvard (1993).

33 Schuster (1995, pp. 98-104). The book actually is about Konstanz, but apparently he needed an excursus to Basel to find the right example.

34 Dinges in Sieferle, Breuninger (1998, pp. 178 (quote), 180).

35 Dinges (1994, p. 337). 
force to the medieval period. All human behavior, also in societies with low levels of affect control, depends to a high degree upon prior learning ${ }^{36}$. To get angry and aggressive, you first need a reason, however suddenly found. You have to differentiate situations with a friendly atmosphere from situations of hostility. In almost every society, people who attack and kill for no apparent reason have been considered mad. The caricature which some historians paint of Elias' view of the middle ages is that of a society of madmen.

Moreover, Dinges' argument that ritual facilitates the peaceful resolution of a conflict before it escalates, even if it were true, is besides the point. To facilitate is not to guarantee automatically. Recurrently, the adherence to ritual failed to prevent bloodshed, in Gauvard's middle ages no less than in Dinges' eighteenth century. The homicide rates suggest this happened more frequently in the former period. Dinges only proves (although this is important in itself) that a lot of minor violence in eighteenth-century Paris still was highly ritualized. It should be added that he concentrated on cases involving honor. What about the violence used in robberies, for example; did it have a more instrumental character? Also, in the absence of a reliable indicator for the quantitative incidence of assaults and fights («real crime»), we are ignorant how the sheer number of the cases studied relates to that in earlier and later periods: in Paris, in France, in the rest of Europe.

Taken together, the criticisms from Dinges and the medievalists want to have it both ways. If they can't disprove the theory of civilization on quantitative grounds, because of high levels of violence in the fourteenth and fifteenth centuries, they point at ritual and argue that attackers actually displayed a great amount of selfcontrol. If they cannot find much ritual, as in nineteenth-century Europe, they claim quantitatively high levels of assault and marital abuse, as we saw, no longer bothering about the question whether this involved controlled violence.

If the practice of ritual and an attachment to one's honor are compatible with free-floating emotions, the study of these themes can be integrated into the theory of civilization. A host of recent studies have shown the prevalence of honorific violence in the rural and urban communities of preindustrial Europe. For some historians, the popularity of this subject is sufficient reason to consider Elias' approach antequated ${ }^{37}$. However, the novelty of a theme says nothing about its implication for existing theories. In an attempt to endow these modern studies with a common program, Schwerhoff calls them microhistories, in which violence is analyzed «as part of an old European culture of conflict and struggle ${ }^{38}$. Apart from the fact that this formula smacks a bit too much of old German Volkskunde, he simply provides no alternative theory. The microhistories have supplied us with a mass of empirical data, showing that, at different times and places, violent confrontations were cases of a defense of a person's honor. The task before us now is to explore new roads leading toward insights transcending this purely empirical observation. In that task, the theory of civilization still is a formidable base from which to proceed.

\footnotetext{
36 Compare Elias (1991).

37 Compare Roodenburg, who opposes Elias' approach to an unspecified «modern cultural history» (review of Johnson, Monkkonen in CHS, 2000,4, 1, p. 137). To be sure, Elias dealt with the concept of honor in his discussion of dueling in Elias (1992).
}

38

Schwerhoff (1999, p. 121). 
The present author has made a modest attempt in this direction. First, I postulated that impulsive $v s$ planned violence and ritual $v s$ instrumental violence were the end poles of two largely independent axes ${ }^{39}$. This notion of axes has proved useful in a study of modern Brazil ${ }^{40}$. Second, I pointed at changes in the concept of honor over the last few centuries, which loosened its connection to violence ${ }^{41}$. In the absence of serious rebuttals, I can simply refer to this earlier work.

It may leave one problem unsolved: killing within the context of a feud frequently has an intentional ring to it (although the original murder triggering a feud often has an impulsive character). That is obvious, for example, in cases in which an enemy is ambushed. Such cases appear to contradict the idea of a long-term trend from impulsive to planned violence. Possibly, my axes are valid only for post-feud phases of social development. Alternatively, we may still acknowledge a certain impulsive element in feuds, to the extent that the timing of an incident can be unexpected, or in view of the often arbitrary choice of which member of a hostile family or faction to attack. We may also see it in the passion with which bloodshed may follow upon bloodshed in long-lasting vendettas, or even in sudden changes of mood from enmity to forgiveness, sealed by a reconciliation ritual, which Elias considers as typical for the society in question. Moreover, the practice of feuding usually involves a love of slaughter and the association of human enemies to a hunting prey, an attitude magisterially described by Edward Muir ${ }^{42}$. There is sufficient reason, then, to rank the physical attacks and killings occasioned by feuds closer to the impulsive than to the planned pole.

The third cluster of problems, the interdependence of long-term change in the field of aggression and human emotions on the one hand and the overall development of society on the other, touches on the very core of the theory of civilization. In this domain, too, misinterpretations have clouded the discussion at times. According to one incorrect view, Elias' theory simply postulates a long-term decline of violence in every social domain. If physical punishment, for example, was on the rise in the sixteenth century compared to the preceding period, this would constitute a problem ${ }^{43}$. However, the death penalties of the sixteenth century primarily were a function of the growth and stabilization of state monopolies. These judicial executions should rather be put on a par with the feuds by which social control and regulation were achieved previously. With the growth and stabilization of state monopolies, the paradoxical situation emerged of a combination of collective violence directed outward and a relative pacification of social relations, with law enforcement as an exception, inside ${ }^{44}$.

Linguistic peculiarities have caused some confusion in this respect. The term «monopoly of violence», commonly used in English, is actually misleading. First,

39 Spierenburg in Johnson, Monkkonen (1996, pp. 70-71).

40 Souza (1999).

$41 C f$. my contributions, notably the introduction, to Spierenburg (1998).

42 Muir (1993).

43 See, for example, the review of De Verbroken Betovering by Florike Egmond in NRC-Handelsblad, March 5, 1999.

$44 C f$. Goudsblom (1998). Roché is one more author who notes this (speaking of most of the 20th century): «On ne peut pas dire que le monde est plus pacifique et moins violent comme un tout. Simplement, les relations interindividuelles étaient plus pacifiques...» $(1998$, p. 2, note 1). 
the monopoly is always relative, since the very assaults and killings discussed here imply an encroachment on it. Second, following Weber, Elias spoke of a Gewaltmonopol; the German word Gewalt originally connoted something like «ability to rule $»^{45}$. Although this obviously has to do with power, it is incorrect to say «monopoly of power». Elias emphasized that power is an aspect of all social relationships; that it is always two-sided. Although the power balance between those who rule and those who are ruled is unequal, the latter have a measure of power too. Thus, by definition, power can never be monopolized. My proposal is to translate Gewaltmonopol as «military monopoly». As Elias demonstrated, its gradual formation was intertwined with that of a monopoly on levying taxes. These two aspects, military ascendency and taxation, together made up the state monopoly, a number of which were established in Europe during the early modern period. Within the theory of civilization this is a crucial, but by no means the only social development which facilitated changes in behavioral standards.

To denote these changes in behavioral standards in English, the term «civilizing process» is common, whereas "process of civilization» actually would be better. The former term suggests that a person or group out there is actively civilizing others, which, in its turn, might suggest that social processes come about because someone directs them. That is never the case. Long-term processes, also that of civilization, are largely «blind». Thus, the refinement of manners in early modern France received an impetus because middle groups imitated the court elite, whereupon the latter were forced to revise their manners in order to maintain social distinction. On the other hand, throughout history some people have tried indeed to change the behavior of others, often in the direction of «more civilized» standards. If this effort involves a more or less concerted campaign, we may speak of a civilization offensive. The «invention of modern man", as Muchembled calls it, in fact represented a major offensive of this type. During a period stretching from the late sixteenth century to the middle of the eighteenth, we frequently observe concerted efforts, through courts and other agencies, to impose norms and standards of behavior implying a more sober way of life, a decrease of magic in people's world view, a more controlled sexuality, etc. ${ }^{46}$. The word offensive, of course, does not necessarily imply success. Like similar ones, this concerted campaign itself was part of a more encompassing, blind process. For example, if the behavior of peasants in 1800 differed from that in 1500 , this was not merely due to the offensives of courts and moral entrepreneurs, but it was also facilitated by social and economic transformations. Both the imitation-and-refinement mechanism and that of conscious inculcation of norms in their turn formed part of overall blind changes.

Thus, the various interdependencies - such as the intertwinement of the growth of state monopolies and the spread of «civilized» codes of behavior - were of a

45 I already discussed this in the introduction of my dissertation (Spierenburg, 1978). Today, German historians freely use «Gewalt» with reference to interpersonal violence. Dinges, however, appears to draw on the older connotation of Gewalt, when he unjustly accuses me of overlooking state violence (in Sieferle, Breuninger, 1998, p. 173). A comparable terminological confusion is evident in a debate among French historians on Elias (Burguière et al., 1995). In that debate, Chartier's definition of interpersonal violence «comme mise en jeu des corps pouvant amener la mise en jeu de l'existence» (p. 231) is well-taken. For his part, Elias hardly used the word violence; to denote affects of aggression, he spoke of «Angriffslust».

46 Muchembled (1988). It should be noted that the singular abstract of «modern man» is quite unlike Elias' approach. 
complex nature. Moreover, these interdependent developments were structured differently in various parts of Europe. Still another mistaken view is that Elias somehow considered court society - and the French model at that - as a necessary stage, without which the process of civilization is unthinkable ${ }^{47}$. Admittedly, he concentrated on France in his 1939 book and published a separate study of the French court. But once more, it is unfair to evaluate his contribution to les sciences humaines based only on these two books. Elias later wrote about quite different social formations and other scholars have done so, using his approach. He always called for new research, which might lead to modificatons of his theory. The appropriate reaction, therefore, is to take up that challenge, rather than simply reproaching Elias for not having done all the work himself.

When we acknowledge that the road through court society was not necessarily the only route for civilization processes, there is no particular reason why we should expect to find that countries or territories with an absolutist regime first witnessed the decline of homicide ${ }^{48}$. To the contrary, they are more likely to have been slower in this respect. As Elias himself pointed out, the recently «tamed» court aristocrats of Louis XIV still carried swords and their renunciation of violence was based on Fremdzwang (external constraints) rather than Selbstzwang (automatic self-constraint). In this environment, the etiquette of table manners and polite conversation, rather than the curbing of anger, formed the main arena for changes in behavioral codes. This is far from an anomaly, since the theory of civilization is about overall societal change, stressing the interdependence of macro-psychological and social, or inter-human, processes. On the most general level, Elias identifies processes of differentiation of functions and extension of the chains of interdependence ${ }^{49}$. These include urbanization, for example, or economic differentiation, which might equally have affected specific spurts in the long-term trend of declining violence.

We are of course seriously handicapped, if we want to find out how the coming of court society affected interpersonal violence in France. The utter lack of French homicide rates for the pre-statistical period makes this enterprise nearly impossible. It is the nefarious legacy of the violence au vol thesis, which has given rise to a fatal preoccupation with percentages. Almost every French historian appears to be convinced that determining the ratio of (prosecuted) violent offenses to property offenses is the real thing. Consequently, France is a blank spot on the European chart of the long-term development of homicide. To remedy that situation is one of the principal requirements for furthering our understanding of interpersonal violence in the past.

Finally, the present. How does the new wave of interpersonal violence in the Western world in the late twentieth century relate to the theory of civilization? For

47 Even while acknowledging that Elias stressed the different routes taken by England and Germany, Schwerhoff (1998, pp. 584-590), makes this mistake. He considers even the smallest detail on which a non-French court deviated from Versailles as a refutation of Elias' theory. Moreover, it eludes me why « communication between ruler and leading elite» and "patronage exchange» are incompatible with the domestication of the aristocracy (p. 584). Finally, Schwerhoff (p. 588) chides Elias for insisting on the term «absolutism», whereas Elias (1969) consistently called this a term used by others.

49 Schwerhoff $(1998$, p. 593) unduly depreciates these as «residual, auxiliary arguments ». 
those who think this theory is evolutionistic or teleological, the answer is simple. The accusation of evolutionism, however, can be ignored, since it is based on the unscholarly procedure of apportioning guilt by association: Elias' work is first pronounced akin to nineteenth-century theories and next every shortcoming of these theories is held against him as well ${ }^{50}$. The theory of civilization is of course based on observed past trends and has no room for evolution. Future generations may witness social integration at even higher levels than the state or they may not.

To illuminate the present, we have to turn to the distant past for a moment. The theory of civilization essentially maintains that a few general societal developments roughly march together: toward increasing differentiation of functions and an extension of the chains of interdependence or in the opposite direction. There are sufficient examples of sustained de-integration in the past, of which the decline and fall of the Roman Empire in the West is probably the best known case. The breakdown of the Roman state monopoly and the concomitant de-differentiation of functions were accompanied in their turn by a decrease in average affect control. There are enough indications to maintain that, during the Principate, the Roman elites had a measure of sensitivity and «civilized' emotional control roughly similar to that prevailing among the aristocracy and higher bourgeoisie of France or England around 1700 . If we could get homicide rates for Europe South of the Rhine and Danube in the first five centuries of the Common Era, the theory of civilization expects them to be lowest in the first and second centuries and then start on a secular rise, along with the breakdown of central state control and economic de-differentiation.

The example of Corsica, with which I began, forms another case in point. Neither the Genoan city-state nor the French national state during the first century of its hegemony could exercise an effective military monopoly over the island, while the level of economic integration and urbanization remained ephemeral during this period. The corollary was a persistence of high levels of interpersonal violence ${ }^{51}$. A recent, more short-term example concerns the devolution of the Soviet Union. In this case, a weakening of the state monopoly is accompanied by rising homicide rates. What happened in Corsica and the former Soviet Union, is precisely what the theory of civilization would lead us to expect. In a similar vein, the increase in interpersonal violence in the Western world from the 1970s through 1990s was partly due to the emergence of unpacified islands in the inner cities ${ }^{52}$.

Nevertheless, the very long-term, or world-historical trend rather proceeds in the opposite direction. Periods of de-differentiation and de-civilization have usually been followed by renewed integration. The world-historical trend lends some plausibility to the expectation of integration at a higher level somewhere in the future. Far from involving wishful, evolutionary thinking, this is a realistic prospect (and it is per definition not wishful for those who hate the idea). In the long run, societies with greater integration and affect control tend to prevail over societies with lesser integration and affect control. This is not due to the presence of some Hegelian

so Recently, Schwerhoff $(1998$, p. 595$)$ used this procedure. Thome (this issue) also speaks of an evolutionary component.

51 A similar situation prevailed in Sicily. Cf. Blok (1974), who, however, does not provide homicide rates.

52 Cf. Spierenburg in Johnson, Monkkonen (1996, p. 95). This argument was first put forward (implicitly) in Anderson (1994). 
world spirit or because someone planned it in advance; it is our empirical observation in retrospect.

Even if we expect renewed integration and civilization in the future, we are ignorant about its timing. Are we to assume, with Thome in this issue, that the trend toward rising interpersonal violence will be with us for a while? That is a mere prediction of course. One cannot explain a predicted trend, only make the prediction plausible. A minor argument against its plausibility is the slight decrease in the homicide rate observed in the USA at the closing of the 1990s. An argument for the stability of the trend observed since the 1970 s, on the other hand, is that it appears to be accompanied by the «revival» of a traditional notion of male honor. For a full appreciation of modern developments, however, a more distant past needs to be taken into consideration.

One longer-term trend has remained undeflected in Western societies until the present day, despite the recent increase in the homicide rate. I am referring to the pacification of the elites. Well into the seventeenth century it had been common for aristocrats and rich burghers to engage personally in physical struggles. This has become ever more uncommon for them since, with the revival of dueling among the nineteenth-century bourgeoisie as a partial exception ${ }^{53}$. Throughout the twentieth century, the West's upper and middle classes have largely refrained from fighting in daily life, considering this a negative habit of men from the lower classes or even an under-class. In today's world, if you want to rise socially, you have to repress whatever violent inclinations you might cherish. Cultures of violence are associated with outsider groups, which appears from, among others, studies of New York in the 1950 s and contemporary towns in America and the Netherlands ${ }^{54}$. The reality of the process of pacification of the elites, for once, is attested by Elias' stern critics together. Schuster shows that the patriciate of Konstanz eagerly partook of the town's violence in the fifteenth century. For eighteenth-century Paris, Dinges points out that, whereas middle groups still indulged in physical confrontations, the upper groups were uninvolved. Schwerhoff admits to the social marginalization of violence in Germany, explaining that its practice was largely confined to the working classes by the second half of the nineteenth century ${ }^{55}$.

The persistence of a relative marginalization of physical aggression, despite the rise in homicide rates in recent decades, attests to the fact that we have not simply returned today to an earlier phase in the long-term development of interpersonal violence. At various levels, modern social circumstances co-determine the ways in which threats, fights and assaults manifest themselves in our world. This can be illustrated with a qualitative comparison. The comparison - preliminary as it must be within the confines of this essay - is between two groups who are relatively wellresearched: Amsterdam's popular duelists around 1700 and the «street-oriented » inhabitants of Philadelphia's inner city, mostly black, on the eve of the year $2000^{56}$. I will call them AM1700 and $\mathrm{PH} 2000$, respectively. The former are representative for a broader culture of violence in the preindustrial period, while several of the latter's characteristics may also apply to underprivileged groups in contemporary

s3 Spierenburg in Spierenburg (1998, p. 24).

54 Schneider (1999); Anderson (1999); van San (1998).

55 Schuster (1995, p. 112); Dinges (1993, p. 384); Schwerhoff (1999, pp. 129-130).

56 Amsterdam: Spierenburg (1998, chapter 4 \& 2000, pp. 188-189); Philadelphia: Anderson (1999). 
Europe. Although AM1700 and PH2000 share a culture of violence and a code of honor and male bravery, at least three crucial differences between them can be observed.

One is obvious at first sight: the use of knives vs. a preference for guns. This difference of technology affects the psychology of the two groups. In a gun fight, the participants usually observe a measure of physical distance, in contrast to the more direct, skin-close confrontation of the bladed duel. More so than with shooting, handling a knife involves the unleashing of aggressive impulses. Paradoxically, those aggressive impulses do not necessarily imply a drive to kill. Knife fighters wanted to teach their opponent a lesson; if the fight ended in death, they considered this an accident. With a bullet, it is nearly impossible to «hurt someone just a little bit». The middle road between backing off and a deadly fight hardly exists. Consequently, to cultivate and exhibit a reputation for violence functions as a strategy of survival: this reputation alone frightens off challengers. For PH2000, unlike for AM1700, every armed confrontation is potentially lethal.

A second difference has to do with modern developments, such as the communications revolution, the rise of consumerism and globalization, all of which had not set in yet by 1700 . Despite the underprivileged conditions, modern media, in particular television, are present in today's inner cities. As a window on the world, television makes PH 2000 conscious of their position outside mainstream society. They hate «the system" and they ridicule and thwart any individual who seeks a future outside the ghetto. Such a form of political consciousness was totally absent in AM1700. Modern media also display the newest products. PH2000 have a taste for expensive trademark articles, which induces them to street robbery at times. This consumer-mentality hardly characterized AM1700. Yet, some of them engaged in property crime as well, in particular to facilitate their principal type of consumption: in taverns. Bars and similar establishments appear to be less central again in the life of PH2000, who literally have a street culture.

Finally, the drug trade permeates modern street life. This is unequivocally a recent phenomenon, in America no less than in Europe. New York gangs of the 1950 s, for example, still were untouched by it. The very people who are habitually violent and cherish an ethos of bravery, are recruited into the illegal economy. Among PH2000, everyone with a «street» orientation gets involved in the drug trade («going legal») sooner or later. This makes it possible for them to stay outside «the system » indeed. By contrast, AM1700 periodically shifted to a legal existence by enlisting on a ship. To the extent that the drug trade helps to sustain the culture of street violence, Western legislators, by prohibiting the consumption of certain substances, indirectly foster that culture.

These observations, the beginning of a comparison which should be elaborated much more fully, are indicative. They point at crucial features of the context of violence which a straightforward count of dead bodies is unable to reveal. The differences between AM1700 and PH2000 illustrate still another aspect of Elias' theory. Elements of earlier phases of a long-term development, he observed, often remain present or return during later phases. However, they usually do so in a transformed manner, commensurate with the different type of society (or «figuration») which has emerged.

Thus, the explanatory potential, for violence and other social phenomena, of the theory of civilization remains strong. That a few details in Elias' 1939 book have failed to stand the test of time was only to be expected. In no way do these minor 
modifications add up to a falsification of his theory and, more important, they are heavily outweighed by new data compatible with this theory. For example, a reexamination of the chronicles Elias indirectly relied on to picture medieval knights' love for battle and slaughter has made the notion of a warrior's lust for attacking uncertain, but this does hardly diminish the reality of violence in the everyday life of the period ${ }^{57}$. Similarly, although gender differences were a less prominent theme in Elias' 1939 book, he was one of the first theorists to include shifting power balances between the sexes among the principal modern trends ${ }^{58}$. Within the body of knowledge generated by Elias himself and the scholars who have elaborated his theories, the triad of gender, power and violence looms large indeed.

The basic argument of this essay can be summed up in a few sentences. Research on the long-term development of homicide over the last twenty years has yielded impressive new evidence for the theory of civilization. Some historians tend to ignore this evidence or attempt to explain it away. The only objection to the theory not based on a misinterpretation refers to the historical study of honor and ritual. However, in so far as they refer to this subject, Elias' critics merely proclaim its modernity, over the alleged «old-fashionedness» of his approach. In reality, the theory of civilization invites creative elaboration, in which subjects like ritual and honor are a boon rather than a problem.

Pieter C. Spierenburg
Faculteit Historische en Kunstwetenschappen
Erasmus Universiteit
Postbus 1738
3000 DR Rotterdam
Netherland
spierenburg@ fhk.eur.nl

\section{BIBLOGRAPHY}

Anderson (E.), The code of the streets, Atlantic Monthly, May 1994, pp. 81-94.

Anderson (E.), Code of the Street. Decency, Violence and the Moral Life of the Inner City, New York, London (Norton), 1999.

Arrighi (P.), (Ed.), Histoire de la Corse, Toulouse, Privat, 1971.

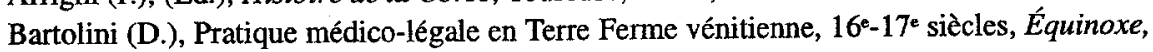
22, Automne 1999, pp. 27-39.

Beattie (J.M.), Crime and the Courts in England, 1660-1800, Oxford, 1986.

Becker (M.B.), Changing patterns of violence and justice in 14th - and 15th-century Florence, Comparative Studies in Society and History, 1976, 18, 3, pp. 281-296.

57 Compare Maso (1982). Schwerhoff (1998, pp. 582-583) repeats Maso's critique. It should be added that, himself a sociologist, Elias used existing historical studies for his synthesis, having no ambition to question the way the authors handled their original sources. It is a little unfair to blame him for the shortcomings of an older generation of historians.

58 Elias (1971, p. 76; orig. ed., 1970). This was before women's studies had emerged in academia. 'Thus, any claim that Elias' theory has no place for women and gender is absurd. On gender and violence, with reference to Elias' work: Spierenburg $(1997,1998)$. 
Blok (A.), The Mafia of a Sicilian Village, 1860-1960. A Study of Violent Peasant Entrepreneurs, New York etc., Harper \& Row, 1974.

Burguière (A.) et al., L'œuvre de Norbert Elias: son contenu, sa réception. Table ronde, Cahiers Internationaux de Sociologie, 1995, 99, pp. 213-235.

Courtwright (D.T.), Violent Land. Single Men and Social Disorder from the Frontier to the Inner City, Cambridge MA, London, Harvard UP, 1996.

Dinges (M.), Ehrenhändel als «Kommunikative Gattungen». Kultureller Wandel und Volkskulturbegriff, Archiv für Kulturgeschichte, 1993, 75, 2, pp. 359-393.

Dinges (M.), Der Maurermeister und der Finanzrichter. Ehre, Geld und soziale Kontrolle im Paris des 18. Jahrhunderts, Göttingen, 1994.

Eck (C. van), Door bloed gezuiverd. Eerwraak onder Turken in Nederland, Amsterdam, Prometheus, 2001.

Eisner (M.), Modernization, Self-Control and Violence. The Long-Term Dynamics of European Homicide Rates in Theoretical Perspective, Paper presented at the European Social Science History Conference, Amsterdam, April 2000 (forthcoming, British Journal of Criminology, 2001, 4).

Elias (N.), Über den Prozess der Zivilisation. Soziogenetische und psychogenetische Untersuchungen, 2 vols, Bern, Haus zum Falcken, 1939.

Elias (N.), Die höfische Gesellschaft. Untersuchungen zur Soziologie des Königtums und der höfischen Aristokratie, Neuwied, Berlin, 1969.

Elias (N.), Wat is sociologie, Utrecht, Antwerpen, Spectrum, 1971.

Elias (N.), On human beings and their emotions. A process-sociological essay, in Featherstone (M.) et al., (eds.), The Body. Social Process and Cultural Theory, London etc., 1991, pp. 103-125.

Elias (N.), Studien über die Deutschen. Machtkämpfe und Habitusentwicklung im 19. und 20. Jahrhundert, Frankfurt a.M., 1992.

Gatrell (V.A.C.), The decline of theft and violence in Victorian and Edwardian England, in Gatrell (V.A.C.) et al., (eds.), Crime and the Law. The Social History of Crime in Western Europe since 1500, London, 1980, pp. 238-370.

Gauvard (C.), «De grace especial». Crime, État et société en France à la fin du Moyen-Âge, 2 vols, Paris, 1991.

Gauvard (C.), Violence citadine et réseaux de solidarité. L'exemple français aux $14^{\circ}$ et $15^{\circ}$ siècles, Annales ESC, 1993, 48, 5, pp. 1113-1126.

Goudsblom (J.), De paradox van de pacificatie, Amsterdams Sociologisch Tijdschrift, 1998, 25, 3, pp. 395-406.

Graziani (A.M.), «Comme des oiseaux à la campagne». Banditisme, État et société dans la Corse du $17^{\mathrm{e}}$ siècle, in Ravis-Giordani (G.), Rovere (A.), (eds.), Banditisme et violence sociale dans les sociétés méditerranéennes, Actes du Colloque de Bastia, 27-29 mai 1993, pp. 77-89.

Graziani (A.M.), La Corse génoise. Économie, société, culture. Période moderne, 14531768, Ajaccio, Alain Piazzola, 1997.

Groebner (V.), Der verletzte Körper und die Stadt. Gewalttätigkeit und Gewalt in Nürnberg am Ende des 15. Jahrhunderts, in Lindenberger (T.), Lüdtke (A.), (eds.), Physische Gewalt. Studien zur Geschichte der Neuzeit, Frankfurt a.M., Suhrkamp, 1995, pp. 162189.

Gurr (T.R.), Historical trends in violent crime. A critical review of the evidence, Crime and Justice, An Annual Review of Research, 1981, 3, pp. 295-353.

Hammer (C.I. Jr.), Patterns of homicide in a medieval university town: 14th-century Oxford, Past and Present, 1978, 78, pp. 3-23. 
Johnson (E.A.), Monkkonen (E.H.), (eds.), The Civilization of Crime. Violence in Town and Country since the Middle Ages, Urbana, Chicago, University of Illinois Press, 1996.

Maso (B.), Riddereer en riddermoed. Ontwikkelingen van de aanvalslust in de late middeleeuwen, Sociologische Gids, 1982, 29, pp. 296-325.

Muchembled (R.), L'invention de l'homme moderne. Sensibilités, mours, et comportements collectifs sous l'Ancien Régime, Paris, 1988.

Muir (E.), Mad Blood Stirring. Vendetta \& Factions in Friuli during the Renaissance, Baltimore, London, 1993.

Roché (S.), Sociologie politique de l'insécurité. Violences urbaines, inégalités et globalisation, Paris, PUF, 1998.

Sabean (D.W.), Property, Production and Family in Neckarhausen, 1700-1870, Cambridge etc., 1990.

Salvini (G.), Giustificazione della rivoluzione di Corsica e della ferma risoluzione presa dai Corsi di mai più sottomettersi al dominio di Genova, Corte, Stamperia della Verità, 1758.

San (M. van), Stelen en steken. Delinquent gedrag van Curaçaose jongens in Nederland, Amsterdam, Het Spinhuis, 1998.

Schneider (E.C.), Vampires, Dragons and Egyptian Kings. Youth Gangs in Postwar New York, Princeton, Princeton University Press, 1999.

Schuster (P.), Der gelobte Frieden. Täter, Opfer und Herrschaft im spätmittelalterlichen Konstanz, Konstanz, Universitätsverlag, 1995.

Schwerhoff (G.), Köln im Kreuzverhör. Kriminalität, Herrschaft und Gesellschaft in einer frühneuzeitlichen Stadt, Bonn, Berlin, Bouvier, 1991.

Schwerhoff (G.), Zivilisationsprozess und Geschichtswissenschaft. Norbert Elias' Forschungsparadigma in historischer Sicht, Historische Zeitschrift, 1998, 266, pp. 561605.

Schwerhoff (G.), Aktenkundig und gerichtsnotorisch. Einführung in die historische Kriminalitätsforschung, Tübingen, diskord, 1999.

Sieferle (R.P.), Breuninger (H.), (eds.), Kulturen der Gewalt. Ritualisierung und Symbolisierung von Gewalt in der Geschichte, Frankfurt, New York, Campus, 1998.

Souza (D.M.B. de Lima Dias de), Violência, poder e autoridade em Goiás, Dissertation, University of Brasília, 1999.

Spierenburg (P.C.), Judicial Violence in the Dutch Republic. Corporal Punishment, Executions and Torture in Amsterdam, 1650-1750, Dissertation, University of Amsterdam, 1978.

Spierenburg (P.C.), How violent were women? Court cases in Amsterdam, 1650-1810, Crime, Histoire \& Sociétés/Crime, History \& Societies, 1997, 1, 1, pp. 9-28.

Spierenburg (P.C.), (ed.), Men and Violence. Gender, Honor and Rituals in Modern Europe and America, Columbus Ohio, Ohio State University Press, 1998.

Spierenburg (P.C.), Wapens en Geweld in Historisch Perspectief, Tijdschrift voor Criminologie, 2000, 42, 2, pp. 183-190.

Wilson (S.), Feuding, Conflict and Banditry in 19th-Century Corsica, Cambridge etc., Cambridge University Press, 1988. 